\title{
Roads for Communities, Not Commodities: A Qualitative Study of the Consequences of Road Development in Papua, Indonesia
}

\author{
Yulia Indrawati Sari ${ }^{1}$ \\ International Relations Department, Parahyangan Catholic University, Bandung, Indonesia \\ Erman Rahman \\ The Asia Foundation, Jakarta, Indonesia
}

\section{Abstract}

This paper aims to examine the impact of improved road infrastructure on the livelihoods of indigenous Papuans in Indonesia. Using field-based investigations in two Trans-Papua road corridors in two provinces, and interviews with 110 informants, the findings show that while roads provide greater access for indigenous Papuans to local markets and to basic health and education services, they also increase access to consumable goods, increasing economic inequality and tensions between indigenous and migrant groups. The findings also confirm negative environmental impacts of these Trans-Papua roads, due to a rise in consumption of natural resources. The study suggests that the government needs to reconsider the focus of its infrastructure development strategies in Papua, from accelerating economic growth ("commodities") to improving the livelihood and access of indigenous Papuans to basic services ("communities").

Keywords: impact of infrastructure, infrastructure development, sustainable livelihoods, Papua

Recommended citation (APA 7th ed.)

Sari, Y. I., \& Rahman, E. (2021). Roads for communities, not commodities: A qualitative study of the consequences of road development in Papua, Indonesia. Human Ecology Review, 27(1), 139-161. doi.org/10.22459/HER.27.01.2021.08

1 Corresponding author: yulia.sari@unpar.ac.id. 


\section{Introduction}

Infrastructure is argued to play a significant role in stimulating economic growth and improving the standard of living in, particularly, low- and middle-income countries (LMICs) (Rozenberg \& Fay, 2019). Many LMICs have invested and will continue to invest in infrastructure development (Gurara et al., 2018), including Indonesia (Bappenas, 2014). Under President Joko Widodo (commonly known as "Jokowi"), the Indonesian administration has placed infrastructure development high on its agenda. As stated in the National Medium-Term Development Plan for 2015-2019 (Bappenas, 2014), one of the nine priority agendas is "to develop Indonesia from the periphery," indicating a particular focus on those regions located far from the nation's capital, Jakarta, such as Papua.

Papua $^{2}$ is, geographically, the easternmost province in Indonesia and, socioeconomically, the least developed. Papua has abundant natural resources, such as forests/timber, gold, copper, and natural gas, yet the economy is concentrated in only a few places. Indigenous Papuans or orang asli Papua (OAP) live in the remote highland regions of Papua, enduring very limited access to basic services and a low Human Development Index (HDI) (Resosudarmo et al., 2009). Based on the most recent statistics on OAP (BPS 3 Papua Barat, 2010; BPS Papua, 2013), the 18 regencies where OAP make up the vast majority of the population tend to have significantly higher rates of poverty and lower HDI scores relative to the rest of the province.

At the same time, Papua faces ongoing, multilayered conflict. Many studies have examined long-established conflicts between particular OAP groups and the Government of Indonesia, demonstrating how such conflicts are the primary source of OAP deprivation conditions (Chauvel, 2005; Widjojo et al., 2010). Other studies have also highlighted conflict between migrants and OAP (Widjojo et al., 2010), as well as inter-clan conflict (Anderson, 2015).

The Government of Indonesia plans to build a 4,330-kilometer Trans-Papua road, beginning in 2015 and expected to be completed by the end of 2019. ${ }^{4}$ The government is also committed to various infrastructure development programs such as "sea toll roads," airports, and railroads. The national government has prioritized road development to connect major urban centers that are currently

\footnotetext{
2 In this paper we use the term "Papua" in reference to both provinces: we use "Papua Province" and "Papua Barat Province" to refer to the specific provinces.

3 Badan Pusat Statistik Papua/Papua Barat Statistics of Papua/Papua Barat Province[s] (Government agencies).

4 The construction of the Trans-Papua road has not yet been fully completed as planned; the government expects to complete the remaining roads in 2020.

5 A sea toll road is a concept introduced by the Jokowi administration in its first term, to improve port and shipping services by accelerating the interisland movement of goods.
} 
geographically isolated. Such development would, in principle, reduce the price of goods in the remote areas, reduce transportation costs for selling local products, and improve the environment for private investment in Papua.

A large amount of research has focused on the economic and social impacts of road infrastructure development to date, but with varying and often conflicting results. For example, Charlery et al. (2016), Gibson and Rozelle (2003), Khandker et al. (2009), and Wiegand et al. (2017), all of whom apply economic modelling, find a positive relationship between road development and poverty reduction in Nepal, Bangladesh, and Papua New Guinea, and argue that it is the poor that benefit most from infrastructure investment. In contrast, ethnographic studies conducted in both Indonesia (e.g., Laurance, 2019; Porath, 2002; Sloan et al., 2019) and Solomon Islands (e.g., Hobbis, 2019) suggest road improvement projects result in increased peatland and forest conversion, increased social differentiation among indigenous people living in the forest, and increased crime.

While offering valuable insights, most quantitative studies focus on the impact of roads on economic growth and only a few assess the distributional implications of the infrastructure development (e.g., Bajar \& Rajeev, 2015). Although recent qualitative research has started to address these knowledge gaps, research on infrastructure projects has yet to examine the views and experiences of local road users, particularly poor and/or indigenous groups, on connectivity improvement and how this connectivity may affect their social lives and their local natural environment.

This study assesses, qualitatively, the effect of improved connectivity across multiple dimensions of OAP lives and the environment in Papua. The specific objectives of the study are to assess the extent to which improvements in Trans-Papua road infrastructure and connectivity have been accompanied by improvements in: access to consumption of goods, income strategies, access to basic services, social relationships, and protection of the environment. Utilizing the sustainable livelihood (SL) framework (Scoones, 1998, 2009), this study provides greater insight into OAP views regarding the consequences of roads on their lives, beyond the economic dimension.

This paper begins with a description of the method of the study. This is followed by an explanation of the improved connectivity situation and its consequences for the economy, social relations, basic services, and the environment. The findings will then be analyzed and discussed in the last section of the paper, including some recommendations for policy directions. 


\section{Study methods}

\section{Analytical framework: Sustainable livelihood framework}

The Sustainable Livelihood (SL) framework provides a holistic guideline to analyze households' access to diverse resources that shape poor people's ability to make a living in sustainable manner (Chambers \& Conway, 1992; Scoones, 1998, 2009). The framework focuses on both material capital, such as income opportunities and consumption levels, and non-material capital, such as natural resource capacity, basic services, and social relations (Scoones, 2009). These come under four typologies of capital: financial and economic, social, human, and natural capital (Carney, 1998; DFID, 2000). At the same time, the framework acknowledges inequality and different access of people to resources, and hence places poor groups at the focus of analysis (Chambers \& Conway, 1992).

This study uses the SL framework to help identify the effect of roads on OAP access to different types of capital, using the typology outlined above. The first category (financial and economic) helps to examine the effect of improved connectivity on the economic capital of OAP-income opportunities and access to consumption goods. Given the communities were living in remote areas, without improved connectivity, consumption goods are not available. This also includes analysis of who benefits the most, in terms of material wealth, from road improvement. The second category (social) helps to examine the effect of improved road access to social resources - social interaction, both among OAP and between OAP and non-OAP, and relationships of trust. We particularly explore OAP views and experiences on how roads influence tensions and trust among clan members, and with migrants. The third category (human) helps to explore the effect on access to basic services, with emphasis on the education and health sectors. The fourth category (natural) helps to explore the impact on natural resources and natural ecosystems, with an emphasis on the effect of road improvement on activities to extract natural resources. This latter category helps explore OAP experiences on whether roads facilitate them to degrade the environment, such as by logging, increasing amounts of plastic waste, and risking endangered species.

\section{Data collection}

The study employs interviews as the main data collecting method. The interviews generally cover the informants' conditions, experience, and personal perspectives on the changes in road connectivity and their accesses on diverse capitals (including economic capital, access to basic services, social interactions, and access to natural resources). Researchers interviewed approximately 110 informants, consisting of villagers around the roads, drivers or regular road users, central and subnational 
government officials, basic service providers such as local health center staff and teachers, and other relevant road users. In addition, the study team analyzed public documents associated with the development of Papua.

Data was also collected through observation and secondary data collection. The researchers observed road corridors and were accompanied by regular road drivers to observe the conditions and improvement of road infrastructure as well as conditions of the surrounding environment. While tracking and observing Trans-Papua road conditions, researchers stopped by and lived for several days in 26 villages located along and near the road corridors.

The empirical findings presented in this article result from approximately one month of fieldwork. The entire process of data collection was carried out in two fieldwork stages, from May 23 to June 6, 2018, and from June 6 to June 24, 2018.

All transcripts and observation notes from the fieldwork were arranged and categorized systematically into four themes, which are: the effect of infrastructure on informants' access to economic capital, basic services, and social interactions, and the effect of infrastructure on the environment. In each theme, information on informants' experience was also differentiated, between informants in the highland and those in the lowland/coastal areas. This was followed by identifying significant patterns, and finally drawing meaning from the data, guided by the SL framework.

\section{Study location}

This qualitative study was carried out along the Trans-Papua road corridor in both highland and coastal areas in Papua and Papua Barat provinces, because the areas have different characteristics. More OAPs live in highland areas with limited access to infrastructure and basic services and rely more on the use of natural resources. Meanwhile, coastal areas are characterized by a greater mix of OAP and non-OAP populations, better access to services, and more diverse livelihoods. The cases are also selected in road corridors that have been constructed under Jokowi administration.

In Papua province (Figure 1A), the study focuses on the main Trans-Papua corridors that connect Jayapura (capital of Papua province in coastal areas) to Wamena (capital of Jayawijaya, the main hub of the central highland region) and from Wamena to Agats (Regency of Asmat). In this area, researchers tracked accessible road corridors between Jayapura and Waris (Keerom), Wamena and Elelim (Yalimo), and Wamena and Habema (Nduga).

In Papua Barat province (Figure 1B), the study focuses on Trans-Papua corridors that connect two major cities: Sorong and Manokwari. In particular, the study chooses to investigate road corridors from Sorong to Tambrauw (a conservation regency), from Manokwari to Bintuni (logging areas), and from Manokwari to Pegunungan Arfak, then on to Ransiki. 


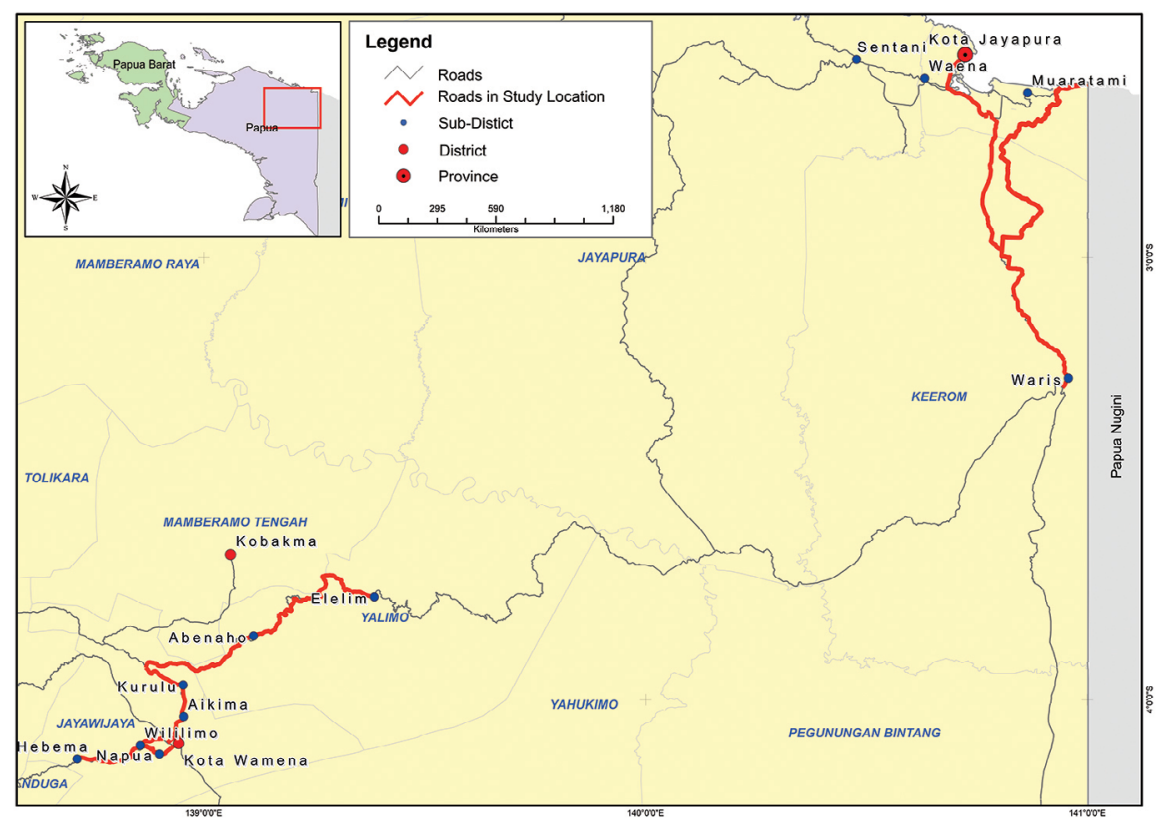

\section{Figure 1A. Study locations in Papua province}

Source: BIG 6 (2019).

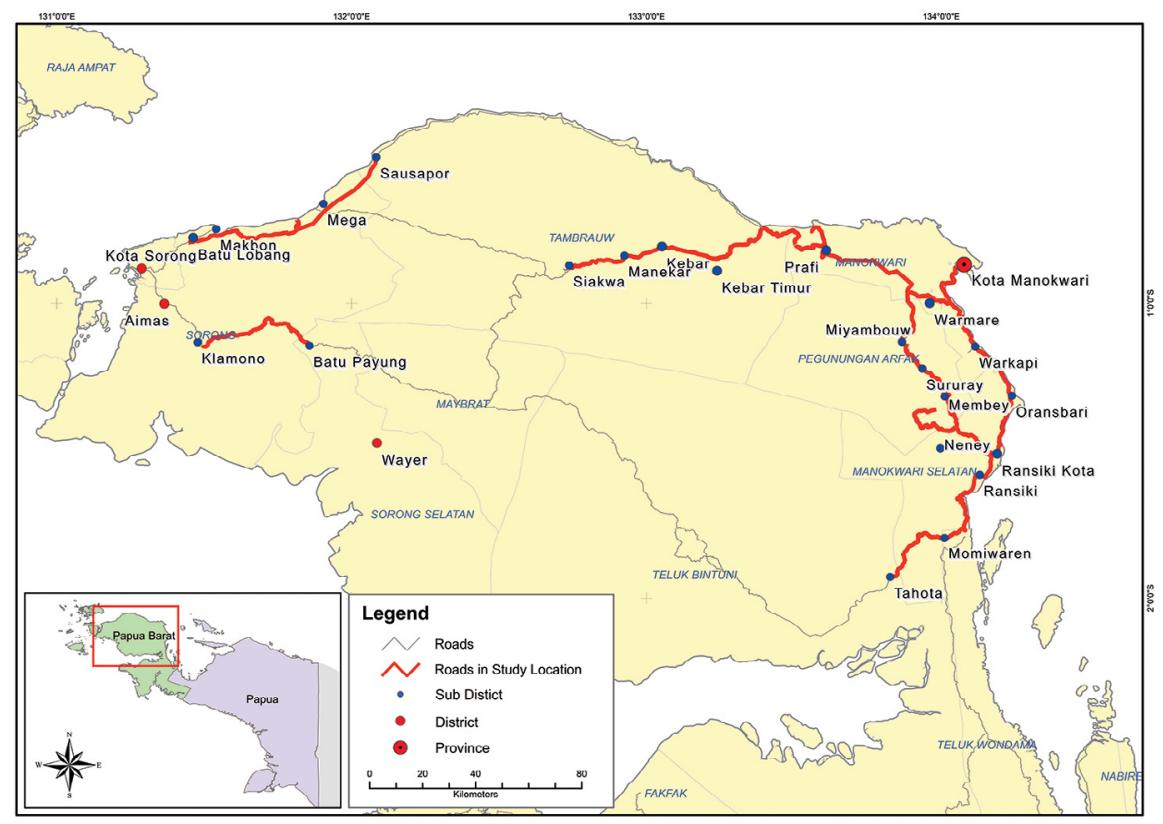

Figure 1B. Study locations in Papua Barat province, and Spatial Planning Information System

Source: BIG (2019) and BAPPEDA Provinsi Papua (2013).

6 Badan Informasi Geospasial, the Indonesian Geospatial Information Agency. 


\section{Findings}

\section{Improved connectivity}

The government uses the length of new road construction as an indicator of improved connectivity. According to statistical data (BPS, 2018, 2015), the Jokowi administration has built approximately 889 kilometers of new national roads in Papua in 2015-2017 - an additional 29\% on the existing 3,074 kilometers of national roads constructed in 2014 or earlier. The construction of new national roads in Papua in 2015-2017 is higher than the national average of 22\%.

However, our study found that the most important aspect of improved connectivity is upgraded road conditions and major road maintenance. Regular road drivers revealed that some national road corridors were first constructed under Suharto's New Order era in 1968-1998 and Susilo Bambang Yudhoyono's administration in 2004-2014. The main difference is that under the Jokowi administration, there has been continuous road maintenance and improvement.

After 2015, existing roads have been better monitored and repaired relatively quickly to maintain the quality of services. Several types of road improvements were identified in the study. Some segments of roads are widened. Non-existent or temporary bridges were replaced with permanent concrete or steel bridges. Gravel and soil roads have been slowly upgraded through continuous soil compaction and pavement. Dangerous and steep sections of roads have been significantly improved by the addition of crushed rocks and continuously compacted as a preparation for pavement in the future.

While the government uses length of roads and types of road surfaces—for example, paved or unpaved - as the main indicators of connectivity, local communities and regular road users define improved connectivity based on the types of vehicles going through the roads. According to them, newly opened soil or gravel roads will lead to the availability of sewa Strada - four-wheel-drive (4WD) cars for rental ${ }^{7}$ — which is very expensive. More demand for public transportation would lead to angkutan Strada (Figure 2), characterized by fixed routes and more affordable prices. Major connectivity improvement is when the roads are served by ojek (motorbike taxi) and/or $A v a n z a,{ }^{8}$ taksi ${ }^{9}$ or Damri ${ }^{10}$ — with fixed routes and prices that can operate all year long.

\footnotetext{
$7 \quad$ Strada is a popular Mitsubishi 4WD double cabin truck. Local people apply the term Strada to all 4WD cars. 8 Avanza is Toyota's most popular compact multi-purpose vehicle in Indonesia. Locals generalize the term Avanza for two-wheel-drive cars.

9 Privately operated—informal and formal—public transportation using a modified non-4WD car with fixed routes and fixed prices.

10 Damri is a state-owned public transportation enterprise.
} 


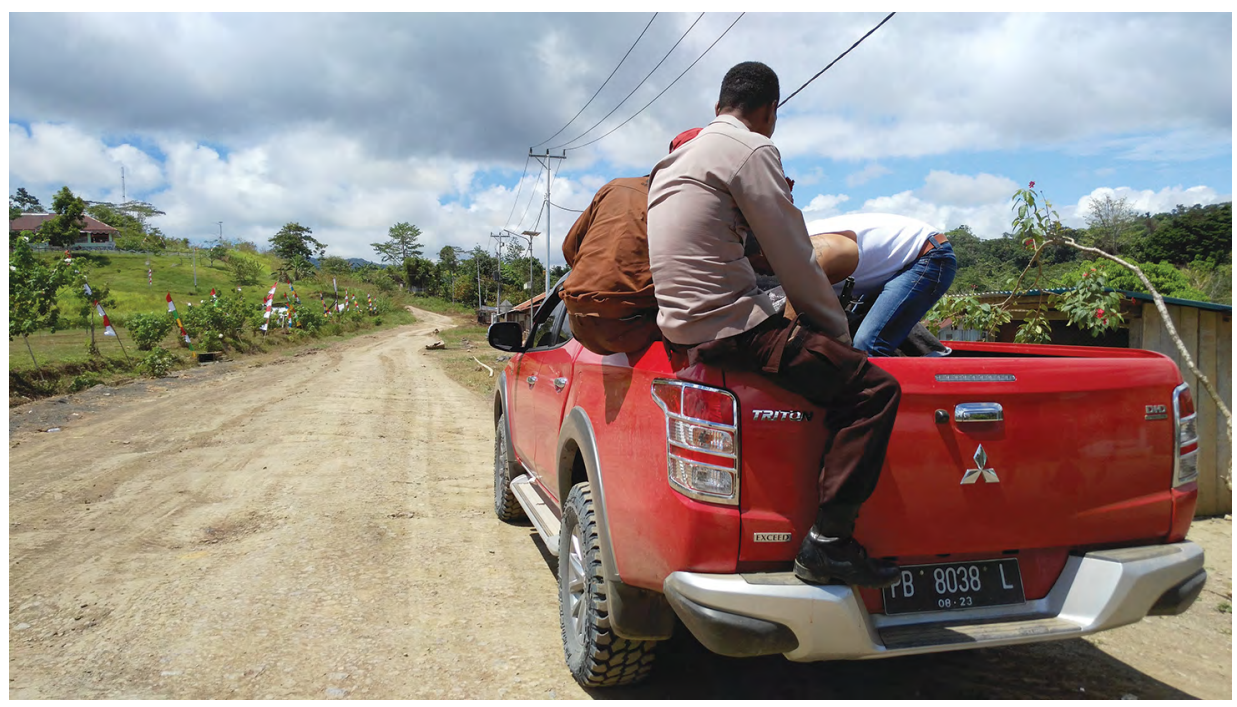

\section{Figure 2. Picture of Strada}

Source: Photo by Muklas Aji Setiawan.

\section{Table 1: Summary of road and connectivity improvements in the study locations}

\begin{tabular}{|l|l|l|}
\hline Route & Road improvement & Connectivity improvement \\
\hline $\begin{array}{l}\text { Sorong-Sausapor } \\
\text { (Tambrauw) }\end{array}$ & $\begin{array}{l}\text { Road repair } \\
\text { Road upgrade } \\
\text { Bridge construction }\end{array}$ & $\begin{array}{l}\text { From sewa Strada to Strada } \\
\text { Reduces travel time from } \\
\text { 8-10 hours to 3-5 hours }\end{array}$ \\
\hline $\begin{array}{l}\text { Manokwari-Ransiki (South } \\
\text { Manokwari)-Tahota (South }\end{array}$ & $\begin{array}{l}\text { Road repair and widening } \\
\text { Road upgrade } \\
\text { Bridge construction }\end{array}$ & $\begin{array}{l}\text { More Strada } \\
\text { Reduces travel time from } \\
\text { 8-10 hours to 5-6 hours }\end{array}$ \\
\hline $\begin{array}{l}\text { Manokwari-Prafi } \\
\text { (Manokwari)-Anggi } \\
\text { Pegunungan Arfak)-Ransiki }\end{array}$ & $\begin{array}{l}\text { Road upgrade } \\
\text { Bridge construction }\end{array}$ & $\begin{array}{l}\text { From sewa Strada to Strada } \\
\text { Reduces travel time from } \\
\text { 8-14 hours to 4-7 hours }\end{array}$ \\
\hline Jayapura-Waris (Keerom) & Major road maintenance & $\begin{array}{l}\text { Informal taksi } \\
\text { Reduces travel time from 4-6 hours } \\
\text { to 3-4 hours }\end{array}$ \\
\hline Wamena-Habema (Nduga) & Road pavement & $\begin{array}{l}\text { From walking on footpath to } \\
\text { informal taksi and ojek }\end{array}$ \\
\hline Wamena-Elelim (Yalimo) & $\begin{array}{l}\text { Road upgrade } \\
\text { Bridge construction }\end{array}$ & $\begin{array}{l}\text { From sewa Strada to Strada } \\
\text { Reduces travel time from 20 hours } \\
\text { to 3-4 hours. }\end{array}$ \\
\hline
\end{tabular}

Note. Regency (kabupaten) name in parentheses.

Source: Interviews with regular drivers and observations. 


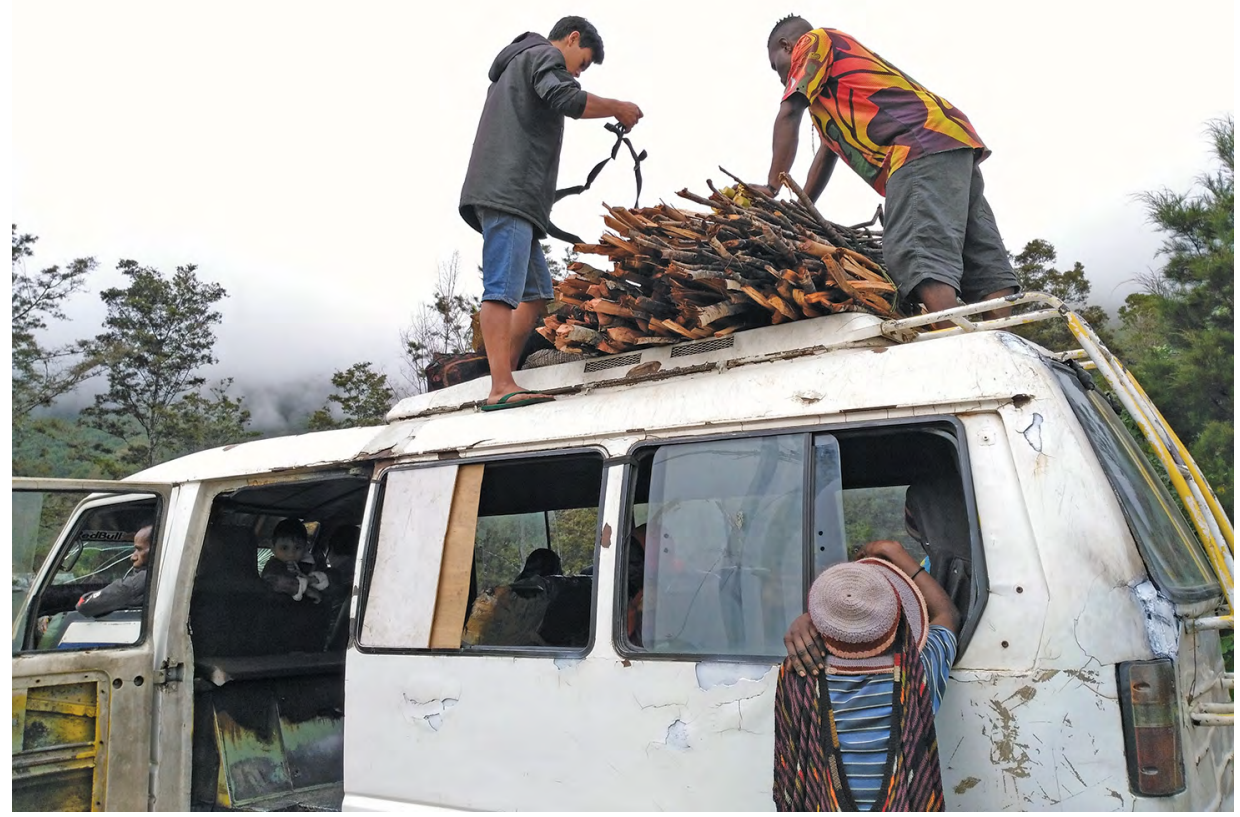

Figure 3. Example of local Taksi in Wamena

Source: Photo by Rizki Ersa Haryana.

The improvement in the type of vehicles means more for locals because it has more impact on reducing driving time and prices. In the locations under study, there are more transportation options and significantly reduced time to reach places, as indicated in Table 1. For example, women in a highland village along the WamenaHabema road segment used to have to carry a noken —Papuan basket_- of their farm produce by walking one to two hours to go down to the market, and then four to five hours to get back home. Since the road was asphalted, there are now ojek and a taksi from their village to Wamena (Figure 3). Now, they prefer to use the taksi, which costs IDR20,000 but takes only 15 to 30 minutes.

\section{Effect of connectivity on access to goods and income strategies}

The study did not find evidence of significant private investment in the 2014-2018 period. Based on the official government statistical data (BPS Papua, 2012, 2015, 2018; BPS Papua Barat, 2015, 2018), investment growth in Papua and Papua Barat provinces was $6.5 \%$ and $5.5 \%$, respectively, in the Jokowi administration, lower than the investment growth of $7.3 \%$ in each province in 2010-2014. 
The contribution of private investment to the overall economy of Papua decreased by $-0.6 \%$ to $26.7 \%$ in $2014-2018$, while in Papua Barat, it slightly increased by $0.5 \%$ to $18.4 \%$ in the same period.

In contrast, the research found significant inflow of "imported goods" at the village level. The effects of improved connectivity to the access of goods and income strategies are different for OAP and migrant communities, among people living in coastal, lowland and highland areas, and between men and women. These will be discussed in this section.

In general, existing migrants, mainly traders and transportation service providers, have better capacity and skills to capture the opportunities created by improved connectivity. They took risks of moving to more remote locations, thereby avoiding increased competition in the urban centers and capturing increased money circulation in rural areas.

Migrant men had been the main providers of "imported goods" prior to the improved connectivity. They sell household goods: cooking ingredients (e.g., salt, sugar, MSG), food and beverages (e.g., instant noodles, snacks, cigarettes, "colored drinks"), and toiletries (e.g., soap, shampoo, toothpaste) to the communities, including OAP. While in urban centers migrants establish shops and kiosks to sell these goods, they access rural and remote areas by "mobile kiosks," their modified motorbikes (Figure 4).

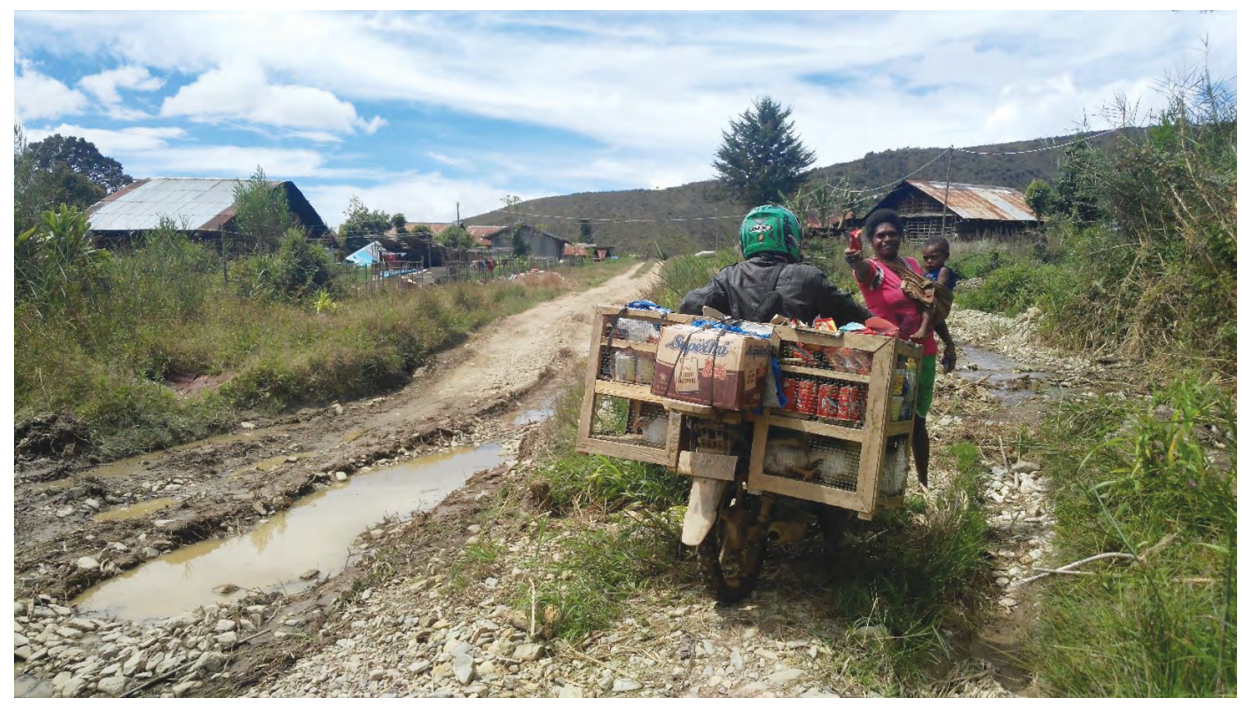

Figure 4. Example of a "mobile kiosk"

Source: Photo by Muklas Aji Setiawan. 
Improved connectivity has allowed them to infiltrate to more remote areas, establish permanent kiosks, and/or diversify their businesses in coastal and highland areas. Migrants usually live in cities and they work as traders to sell goods to OAP in the nearest accessible villages, using modified motorbikes. In return, they buy agricultural products and sell them in the cities. The upgraded roads allow them to infiltrate more villages that are now relatively more accessible, particularly reaching villages in the highlands. Some of them even move and establish new kiosks. Based on our interviews with kiosk owners in Elelim (Yalimo Regency), for instance, the number of kiosks has more than tripled in eight years, from only four in the early 2010s. Some of them have also accumulated their profits in the past to invest in a Strada and expanded from trading to the transportation business.

This market expansion is also accompanied by an influx of processed goods and agriculture and poultry produce from other regions to remote areas in the highlands. Prior to the improved connectivity, local markets in Yalimo, Pegunungan Arfak, and Tambrauw only sold local produce such as taro, sweet potatoes, betel nut, and sago. Now the markets also sell a wider range of vegetables such as cabbage, beans, carrots, and ginger, as well as fish, poultry, beef, and deer meat. The commodities are mainly "imported" from the nearest urban center, but some even come from other large cities such as Jayapura and Merauke.

The increased purchasing power ${ }^{11}$ and variety of goods have changed the consumption behavior of the communities in the highlands. OAP residents who were not used to eating outside their homes now like to buy foods and snacks from the local shops. Mothers lament that their children continuously ask for cash to buy snacks and "colored drinks." While they feel increasing pressure to have cash in hand, they also value this as "being modern." Consuming shampoo, toothpaste, and body soap are considered as the way for OAP to be as "developed" as migrants.

While improved connectivity has allowed OAP women living near national roads in coastal and highland villages to sell their excess produce more frequently in farther markets in the nearest city, such OAP market expansion has not significantly increased their income, mainly due to the micro scale of their production. For OAP women in the highlands, for instance, availability of taksi creates an opportunity for them to increase the volume of their produce from one to two noken (Figure 5), plus one or two bundles of wood. In coastal areas, women mention they have increased the volume of fruit and vegetable harvests. It is not certain how many times in

11 This is associated with an increase in government transfers to the villages through the enactment of the Village Law 6/2014. The law requires central and regency governments to transfer significant amounts of funds to the villages. It is estimated that the average village budget in Papua and West Papua provinces was only Rp212 million in 2013 (USD14,722). Based on Presidential Regulation No. 107/2017 on Detailed State Budget Revenues and Expenditures for Fiscal Year 2018, five years later, the average village budget was Rp2,007 million (USD139,375), almost 10 times that of 2013 (DJPK, 2013, 2018). The funds are mostly used for infrastructure, housing construction, and cash transfer to the communities and, hence, significantly increase the circulation of money at the community level. 
a month they sell produce to market, and most of the time they cannot sell all their excess produce. The small increase in income is also because of limited demand, particularly in harvest seasons. Even in regency-level markets, vegetables and fruits are in oversupply during the harvest seasons. The women sellers are forced to either bring back the unsold produce or leave it behind to reduce their transportation cost to return to their villages.

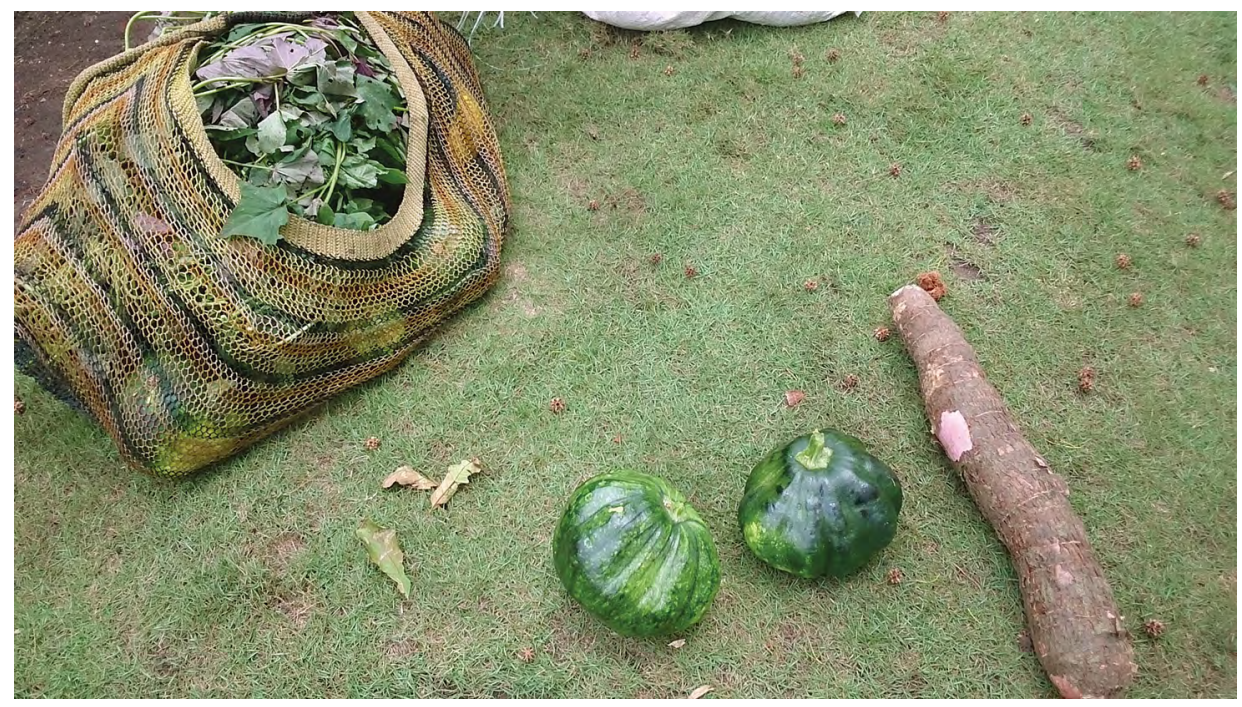

\section{Figure 5. Picture of Noken}

Source: Photo by Yulia Indrawati Sari.

Road upgrading also leads to different livelihood strategies for OAP men living in coastal and in highland areas. OAP men in lowland areas have opportunities to change (or supplement) their livelihoods from agriculture to other sectors. They have started driving ojek and become construction workers. Meanwhile, such alternative livelihood opportunities are not available for OAP men living in the Papuan highlands. They can only extract natural resources to increase their incomes. Increasing demand for wood for house construction incentivizes the men to cut more trees. In highland Tambrauw, OAP men get cash by hunting deer-which was only for private consumption in the past. In a week's hunting, two to three men can kill three to four deer and obtain Rp2-3 million (USD139-208).

\section{Effect of connectivity on social relations}

In general, village residents say that the roads have made it easier to visit relatives living in other villages. They frequently visit relatives not only for a specific occasion, such as a funeral or marriage ceremony, but also to help their relatives to build houses, to build fences, and even to defend their clan members in the case of conflict. 
For Papuans, frequent visits to relatives in other villages are important and help overcome problems in times of difficulty, as their social relations revolve around kinships and they form exclusive ties and linkages (Mansoben, 1995).

The study finds that men and women have different views and perspectives on the important effect of roads on their social lives. The main thing women profoundly mentioned is the opportunity to meet with their children who study outside their villages. It is common that in less accessible villages with a lack of high school services, families send their children to study in urban centers. Improved connectivity increases the frequency of their meetings with their children who attend schools in cities such as Manokwari, Sorong, and Jayapura. Prior to the connectivity improvement, they could only meet their children once or twice a year, or only when the children came home for the Christmas holiday.

For most men, road development symbolizes a gift from central government. For them, any kind of road is good and shows the government cares for the lives of Papuans, indicating the presence of the state. For OAP living in remote areas who have long experienced the absence of the state and its services, road development offers evidence of the government's initiative to provide direct benefits that actually reach them.

The meaning of road improvement is also different from the perspectives of the village heads and clan chiefs. They highlight the improvement in connectivity as an opportunity to enhance their relations with their patrons in big cities, in a hope to gain more cash and projects. They have increased their visits to the regency capital to provide support to "friends" who run for local legislative council (DPRD) membership. They also purposefully meet those who have been elected as DPRD members or appointed as government officials to get cash or to facilitate development programs for their villages. They use their privileged position within the political patronage system to influence those with a political position for resources (money, development projects) in exchange for loyalty and support.

However, the improved connectivity has made relations between OAP and nonOAP more complex. On the one hand, OAP see migrants as an important part of their lives, who supply various needs, safely transport them to their destinations, buy their crops and wood, and can be relied on to build the houses and facilities they need. But on the other hand, the migrants' ability to make use of the improved connectivity creates tension and feelings of being insecure and under threat, and fears that OAP are increasingly marginalized.

These fears and tension are strongly felt primarily in the Central Highland villages. This can be seen, for example, from the narratives they use about the effect roads have on the growing numbers of farm-raised pigs or babi telinga layar coming 
from Jayapura to Wamena, causing the local Wamena pigs to go unsold. They also told stories about how migrants brought larger amounts of alcohol from Jayapura, poisoning the youth and causing more motorcycle accidents.

This reaction to anxiety has manifested, for example, in various forms of verbal restrictions. With growing anxiety, OAP in four observed villages in the Central Highlands have started to prohibit migrants from being more involved in the local economy. They ban migrants from opening kiosks, limit the operating hours of migrants' ojek, and ask migrants to give them more money. One regency head in the highlands even strongly advises residents not to rent land to migrants.

\section{Effect of connectivity on basic services}

In Papua, poor connectivity makes health care and higher education facilities relatively inaccessible. Interviews with residents revealed that OAP access to basic health and education services has generally improved. Better transportation makes it easier for them to reach these services. They said that their children can study at good schools in the urban centers. Instead of carrying sick or injured people to reach community health center (puskesmas), they can ride Strada to go the main hospital in the regency capital.

Interviews with nurses and doctors in puskesmas confirm that road improvement has increased the number of OAP who seek free-of-charge treatment in puskesmas, including those living in remote villages. They seek treatment for various relatively minor complaints such as colds, coughs, aches, and dizziness, something that did not happen in the past. The puskesmas staff do not have exact data on the increasing number of patients after connectivity improvement. However, they estimate that the number of patients on busy days has increased by 10 to 15 patients. From only about 10 patients, now they serve up to around 20 patients per day.

Furthermore, increased connectivity affects the patient referral process. Distance to facilities has been identified as a critical factor which determines patients' decisions to follow up on higher-level services. Interviews with puskesmas officers in the two provinces revealed that improved connectivity has increased the number of patients who seek further treatment to a hospital in the nearest city.

However, the quality of services in remote areas, especially in the education sector, has not shown significant improvement. In remote villages in the highlands and lowlands, women complain about a lack of change in teacher absenteeism. Fulltime teachers are still often absent from teaching. Casual teachers often do most of teaching process. There are even indications that teachers are now absent more often, as better accessibility enables them to do things other than teaching. 
On the other hand, improved connectivity reduces health-worker absenteeism. Interviews with health workers in puskesmas located along the upgraded roads revealed that shorter travel time has incentivized health workers to be present at the health centers. They can routinely meet family in the city and/or they can live in the nearest city. In one puskesmas in Sorong Regency, a doctor said he is happier serving at the puskesmas now since his commuting time is only 45 minutes. Nurses in a puskesmas in Mega (Tambrauw Regency) also highlighted that they do not want to quit their jobs because they can routinely visit their families in Sorong once a month.

In conflict areas in the Central Highlands, the increased number of ojek and cars enhances the feeling of security for puskesmas personnel, which affects their service period. A nurse in the puskesmas of Pelebaga (a subdistrict in Jayawijaya Regency) said that she used to come to work only two to three times a week, with working hours only to midday. Now she feels more secure to come every day from her home in Wamena (capital of Jayawijaya) and works full days.

Unfortunately, the connectivity improvements have not been accompanied by significant improvements in other types of infrastructure, such as electricity and water supplies, as well as road and transportation services from villages to wellfunctioning health and education services. Some puskesmas that are now well functioning are still not equipped with clean water and electricity supplies. They still rely on rainwater reservoirs or water pumps.

\section{Effect of connectivity on environment}

In general, improvement of road connectivity in Papua has had a negative impact on the environment, particularly through increasing logging activities. Complemented by increasing village budgets and village proliferation, ${ }^{12}$ communities are incentivized to open up forests near national roads_-such as in the Sorong-Tambrauw, SorongMaybrat, and Manokwari-Bintuni sections_to establish new villages. High utilization of village budgets for house construction increases the demand for wood and, hence, intensifies logging activities by OAP men.

Furthermore, the penetration of migrants to more remote areas, discussed previously, also increases the demand for logs. While some migrants are micro traders with limited purchasing power, others are allegedly financed by migrants living in urban areas. For example, migrants who used to live in more urbanized Oransbari or Ransiki (both are in South Manokwari) moved to Momi Waren (also in South Manokwari) after improved connectivity, to mobilize OAP to log. Some of the migrated log collectors are linked and financed by bigger log traders in urban centers. While

12 Increased village funding creates incentives for the establishment of new villages. Based on Minister of Home Affairs Regulations Nos. 18/2013 and 72/2019 on Code and Regional Data of Government Administration, the numbers of villages in the two provinces have increased by 15\% in 2013-2019, reaching 7,153 villages in 2019. 
illegal logging is apparent, legal logging activities are also expanding. The logging permits issued by West Papua’s Investment and One Stop Shop Licensing Office have increased in the past few years and reached more than 1,000 in $2017 .{ }^{13}$

Not only the community, but logging companies seemed to increase their production and degrade the environment further. For example, interviews with passengers and transportation operators operating in the Manokwari-Bintuni road segment indicated increasing numbers of trucks operating in the route and an increasing volume of logs transported.

Activities at the community level and by existing large extractive companies have reduced the forest cover in the two provinces. Based on official government data (KLHK, ${ }^{14}$ 2015, 2018), in 2014-2017 Papua lost 234 thousand hectares of forest cover. Although Papua's deforestation rate $(0.7 \%)$ is lower than the national average $(2.6 \%)$, the deforested area in Papua is $9 \%$ of the national level. Forest Watch Indonesia (FWI, 2019) estimates the deforestation rate in Papua has increased from 60 thousand hectares per year in 2000-2009 to 172 thousand hectares per year in 2009-2013, and, even higher, to 189 thousand hectares per year in 2013-2017. FWI estimates that this is due to the expansion of plantations, particularly oil palm, and can be worsened by the rapid infrastructure development under Jokowi administration.

One major example of the lack of environmental consideration in road construction is the Wamena-Habema-Kenyam-Mumugu route that crosses the Lorentz National Park. The park has been acknowledged by the United Nations Educational, Scientific and Educational Organization as a world heritage site since 1999 (UNESCO, 2004). Starting in 2004, the World Heritage Committee (WHC) raised concerns about road development in Habema and asked the Indonesian Government to conduct an environmental impact assessment (EIA) (UNESCO, 2004). While the government has not implemented the EIA, it continued constructing the 90 kilometers of Habema-Kenyam road until 2014, leaving only 22 kilometers unbuilt, although WHC asked them to stop in 2008 (UNESCO, 2017). WHC only received the revised EIA of the road construction in 2016 (UNESCO, 2017). The EIA states that the road is environmentally feasible, albeit recognizing significant environmental impacts. Discussions in the field revealed that the road construction has been continued with a high degree of involvement of the army.

In villages, the study identifies further cases of the negative effect of upgraded roads on the environment. An ecotourism operator in Mokwam Village in Pegunungan Arfak feels that road development has caused various species of endemic birds and animals to move further into the forest. Tourists have to walk further into the forest

13 Head of West Papua’s Provincial Investment and Licensing Office in Manokwari (personal communication, August 7, 2018).

14 Kementerian Lingkungan Hidup dan Kehutanan, Indonesia’s Ministry of Environment and Forestry. 
to see them, and this can disturb the forest ecosystem. The increasing availability of "imported goods" discussed earlier also increases plastic waste in rural areas. Village customary (adat) leaders have started complaining about plastic pollution in their rivers and lands. The study team also observed waste of food, beverage, and toiletry packages on the ground or flowing in the rivers of remote rural Papua.

\section{Discussion and conclusion}

This study aims to understand the effect of road connectivity on people's access to various livelihood assets_-economic, social, basic service and environmentalparticularly from the perspective of the indigenous people (OAP) who live along the road development project in Papua. The findings from this study clearly indicate that infrastructure investments in Papua result in two important outcomes. On the one hand, infrastructure enhances social relations between OAP and improves access to health and education services. Particularly in the health sector, the quality of services_-represented here by less health-worker absenteeism and longer service hours - has also improved, as the health workers feel more comfortable to provide these services, given the wider varieties of transportation modes for commuting.

On the other hand, this study also finds that infrastructure development has led to increased inequality and tensions between OAP and non-OAP, as well as increasing the potential for greater natural resource extraction. More specifically, this study shows how the economic benefits of road development are not necessarily felt by OAP, who question the distributive aspect of the improved connectivity. Although OAP feel migrants bring them wider varieties of goods and help them to build buildings, OAP in Papuan highlands feel more insecure and threatened by migrants. This study also demonstrates how road improvements change people's livelihood practices at the village level, promoting greater use and extraction of forest resources. Roads facilitate access for more people to sell logs and wood and increase plastic waste and rubbish in soil and rivers.

A clear implication of this research is that road development does not necessarily lead to improved access for poor groups to economic resources and hence increased income. While quantitative studies on the impact of roads on poverty in Papua New Guinea (Gibson \& Rozelle, 2003; Wiegand et al., 2017) argue that poor communities do benefit the most from infrastructure, this study shows how road improvements actually increase inequality between non-OAP and OAP. In particular, this study finds that roads in fact provide more opportunities for migrants to diversify their livelihoods and to take advantage of market-based activities, but provide limited opportunities for OAP to expand their income strategies in a way that does not have significant impact on surrounding natural resources. 
These findings conform with research that focuses on the distributional impact of road infrastructure, indicating that the economic growth that results from infrastructure development does not necessarily lead to a reduction in inequality (Banerjee \& Somanathan, 2007; Porath, 2002). They find that infrastructure services in India have more benefits for higher-income groups than for the poor. Nathan Porath (2002) highlights that the Pekanbaru-Dumai road development did not open more economic opportunities for indigenous (Sakai) communities.

Thus, the narrative that roads bring more benefits and create better standards of living for poor groups is doubtful. Dalakoglou and Harvey (2012, p. 460), in reviewing articles of mobilities on roads and anthropology, indicate that roads act both as a "threat" as much as a "promise." It is true that for many OAP living in remote areas who have long experienced the absence of the state and its services (Anderson, 2015), infrastructure programs offer direct benefits, particularly to access basic services.

However, this research draws attention to the rather alarming implications of road infrastructure for increasingly fragile environments, particularly for OAP. In the context of Papua where inequality, conflict, and rich resources exist, improved connectivity has the potential to amplify the fragile situation for OAP. Increased inequality and tensions between OAP and non-OAP, as well as further environmental degradation as a consequence of road development, will negatively affect the wellbeing of OAP and livelihood possibilities of OAP in the future.

Although these observations were found in Papua, they apply equally to road investments in other regions with similar contexts of inequality and conflict. A recent study, which applied ethnographic and qualitative research methods in Solomon Islands, has highlighted the more nuanced and serious consequences infrastructure development can have on the social and everyday lives of poor people, including increased crime and reduced trust. Hobbis (2019) illustrates how villagers in Gwou'ulu, Solomon Islands, do not experience the imagined goals of roads such as decent job opportunities. Rather, "the sudden maintenance of the North Road became, to many respondents, immediately and primarily visible a source of insecurity in everyday life, rather than as a source of a promised future stability" (Hobbis, 2019, p. 754).

Other assessments on the impacts of road development in West Kalimantan (Wadley, 1998), in Australia (Adam et al., 2011), and in the Amazon (Schmink \& Wood, 1992) also find increased conflict between outsiders and indigenous/local groups, and concerns about local peoples' rights to their spaces and resources in the name of road development. Furthermore, in resource-dependent regions such as Papua and the Amazon, road development increases forest extraction practices that may result in ecological degradation (e.g., Colombijn, 2002; Schmink \& Wood, 1992; Sloan et al., 2019; Wadley, 1998). 
With all the benefits and costs discussed in this paper, this research calls for reorienting road development from neutral, mixed-growth, and equity objectiveswhich actually enhance inequality and social conflict as well as being harmful to the environment-towards equality-focused and sustainable connectivity infrastructure that centers on improving access of the poor to basic services and local markets. The Indonesian Government needs to take into account poor and indigenous groups' views and everyday practices_-social relations within and between outsiders, the capacities of different groups to seize and take advantages of market opportunities, and forest use practice-in planning and constructing roads.

In this case, a plan to invest in big infrastructure that connects major cities is less important than building local roads that connect villagers to local health care and school facilities. The connectivity investments should also be accompanied by improvements in the quality of basic services delivery, provision of water and electricity, affordable public transport, and selective investment criteria which prioritize environmentally sustainable industries. In other words, infrastructure for communities, not commodities.

\section{Acknowledgment}

This paper is based on a study that was jointly conducted by a team from The Asia Foundation (TAF) and Lembaga Ilmu Pengetahuan Indonesia (LIPI) consisting of Yulia Indri Sari, Adriana Elisabeth, Erman A. Rahman, Jonathan McLeod, Cahyo Pamungkas, Rizki Ersa Haryana, Muklas Aji Setiawan, Harry Seldadyo, Aisah Putri Budiatri, Septi Satriani and Anastasya Surya Andjaswari. The team was accompanied by the following local researchers: Muhammad Chamin, Ocha Windesi, Ibrani Nayaki, Florentianus Geong, Rizal Lani, Nelson Lokobal, Kris Ajoi, Yan Baylo, Daniel Mandacan, Yulianus Dowansiba, Reny Suruan, Sandi Hasudungan, Melda Tuannakota, Edwin Ogin Amar, and Mella Kalaibin. The study team thanks the UK Climate Change Unit (UKCCU), which supported this study, TAF's environmental governance team, West Papua's Provincial Research and Development Agency (BALITBANGDA) and Papua's Provincial Development Planning Agency (BAPPEDA). The team was also assisted by Ridwan in making a study map. This paper does not necessarily reflect the positions of TAF, LIPI, UKCCU, or the two provincial governments.

\section{References}

Adam, M. C., Kneeshaw, D., \& Beckley, T. M. (2011). Forestry and road development: Direct and indirect impacts from an Aboriginal perspective. Ecology and Society, 17(4), Article 1. doi.org/10.5751/ES-04976-170401 
Anderson, B. (2015). Papua's insecurity: State failure in the Indonesian periphery. (Policy Studies 73). The East-West Center. www.eastwestcenter.org/system/tdf/private/ps0731.pdf?file $=1 \&$ type $=$ node $\&$ id $=35252$

Bajar, S., \& Rajeev, M. (2015). The impact of infrastructure provisioning on inequality: Evidence from India (Global Labour University Working Paper No. 35), International Labour Organization. hdl.handle.net/10419/121445

Banerjee, A., \& Somanathan, R. (2007). The political economy of public goods: Some evidence from India. Journal of Development Economics, 82, 287-314. doi.org/10.1016/ j.jdeveco.2006.04.005

BAPPEDA Provinsi Papua (Provincial Planning and Development Agency of Papua). (2013). Peraturan Daerah Provinsi Papua nomor 23 tahun 2013 tentang Rencana Tata Ruang Wilayah Provinsi Papua Tahun 2013-2033 [Regional regulation of Papua Province number 23 of 2013: Spatial planning for Papua Province, 2013-2033]. Retrieved January 15, 2020 from simtaru-files.papua.go.id/s/epbqaTnPai7SFsN

Bappenas (National Development Planning Agency). (2014). Lampiran Peraturan Presiden Republik Indonesia Nomor 2 Tahun 2015 tentang Rencana Pembangunan Jangka Menengah Nasional 2015-2019, Buku I: Agenda Pembangunan Nasional [Attachment to the Presidential Regulation No. 2 Year 2015 on National Medium-Term Development Plan 2015-2019, Book I: National Development Agendas].

BIG. (2019). Topographic maps of Indonesia. Badan Informasi Geospasial [Geospatial Information Agency]. Retrieved January 14, 2020 from geoservices.big.go.id/portal/ apps/webappviewer/index.html?id=9917592df1f24501ae804b7d346c08fb

BPS. (2015). Statistical yearbook of Indonesia 2015. Badan Pusat Statistik [Statistics Indonesia].

BPS. (2018). Statistical yearbook of Indonesia 2018. Badan Pusat Statistik [Statistics Indonesia].

BPS Papua. (2012). Papua province in figures 2012. Badan Pusat Statistik Provinsi Papua [Statistics Province of Papua].

BPS Papua. (2013). Papua province in figures 2013. Badan Pusat Statistik Provinsi Papua [Statistics Province of Papua].

BPS Papua. (2015). Papua province in figures 2015. Badan Pusat Statistik Provinsi Papua [Statistics Province of Papua].

BPS Papua. (2018). Papua province in figures 2018. Badan Pusat Statistik Provinsi Papua [Statistics Province of Papua].

BPS Papua Barat. (2010). Papua Barat province in figures 2010. Badan Pusat Statistik Provinsi Papua Barat [Statistics of Papua Barat Province].

BPS Papua Barat. (2015). Papua Barat province in figures 2015. Badan Pusat Statistik Provinsi Papua Barat [Statistics of Papua Barat Province]. 
BPS Papua Barat. (2018). Papua Barat province in figures 2018. Badan Pusat Statistik Provinsi Papua Barat [Statistics of Papua Barat Province].

Carney, D. (1998). Implementing the sustainable rural livelihood approach. In D. Carney (Ed.), Sustainable rural livelihoods: What contribution can we make? (pp. 3-230). Department for International Development (UK).

Chambers, R., \& Conway, G. (1992). Sustainable rural livelihoods: Practical concepts for the 21st century (IDS Discussion Paper 296). Institute of Development Studies.

Charlery, L. C., Qaim, M., \& Smith-Hall, C. (2016). Impact of infrastructure on rural household income and inequality in Nepal. Journal of Development Effectiveness, 8(2), 266-286. doi.org/10.1080/19439342.2015.1079794

Chauvel, R. (2005). Constructing Papuan nationalism: History, ethnicity, and adaptation (Policy Studies 14). East-West Center.

Colombijn, F. (2002). Introduction: On the road. Bijdragen tot de taal-, land-en volkenkundel Journal of the Humanities and Social Sciences of Southeast Asia, 158(4), 595-617. doi.org/ $10.1163 / 22134379-90003757$

Dalakoglou, D., \& Harvey, P. (2012). Roads and anthropology: Ethnographic perspectives on space, time and (im)mobility. Mobilities, 7(4), 459-465. doi.org/10.1080/17450101. 2012.718426

DFID. (2000). Achieving sustainability: Poverty elimination and the environment. Department for International Development.

DJPK. (2013). Fiscal balance sheet 2013. Direktorat Jenderal Perimbangan Keuangan, Kementerian Keuangan (Directorate General of Fiscal Balance, [Indonesian] Ministry of Finance). Retrieved November 14, 2020 from www.djpk.kemenkeu.go.id/?p=5412

DJPK. (2018). Fiscal balance sheet 2018. Direktorat Jenderal Perimbangan Keuangan, Kementerian Keuangan (Directorate General of Fiscal Balance, [Indonesian] Ministry of Finance). Retrieved November 14, 2020 from www.djpk.kemenkeu.go.id/?p=5412

FWI. (2019). Deforestation over time in the land of Papua. Forest Watch Indonesia. fwi.or.id/ wp-content/uploads/2019/02/factsheet_deforestation-in-papua_ENG.pdf

Gibson, J., \& Rozelle, S. (2003). Poverty and access to roads in Papua New Guinea. Economic Development and Cultural Change, 52(1), 159-185. doi.org/10.1086/380424

Gurara, D., Klyuev, V., Mwase, N., \& Presbitero, A. F. (2018). Trends and challenges in infrastructure investment in developing countries. International Development Policy|Revue internationale de politique de développement, 10(1). doi.org/10.4000/poldev.2802

Hobbis, S. K. (2019). A road to development? Rural perspectives on infrastructure maintenance in Solomon Islands. Development in Practice, 29(6), 748-759. doi.org/ $10.1080 / 09614524.2019 .1586832$ 
Khandker, S. R., Bakht, Z., \& Koolwal, G,B. (2009) The poverty impact of rural roads: Evidence from Bangladesh. Economic Development and Cultural Change, 57(4), 685-722. doi.org/10.1086/598765

KLHK. (2015). Statistics of the environment and forestry 2014. Kementerian Lingkungan Hidup dan Kehutanan [Ministry of Environment and Forestry (Indonesia)].

KLHK. (2018). Statistics of the environment and forestry 2017. Ministry of Environment and Forestry [Ministry of Environment and Forestry (Indonesia)].

Laurance, W. (2019, January 17). A highway megaproject tears at the heart of New Guinea's rainforest. Yale Environment 360. e360.yale.edu/features/a-highway-megaproject-tearsat-the-heart-of-papuas-rainforest

Mansoben, J. R. (1995). Sistem politik tradisional di Papua [The traditional political system in Papua]. Lembaga Ilmu Pengetahuan Indonesia [Indonesian Science Institute] (LIPI) and Leiden University.

Porath, N. (2002). A river, a road, an indigenous people and an entangled landscape in Riau, Indonesia. Bijdragen tot de Taal-, Land-en VolkenkundelJournal of the Humanities and Social Sciences of Southeast Asia, 158(4), 769-779. doi.org/10.1163/2213437990003766

Resosudarmo, B. P., Napitupulu, L., Manning, C. \& Wanggai, V. (2009). Papua: Challenges of economic development in an era of political and economic change. In B. P. Resosudarmo \& F. Jotzo (Eds.), Working with nature against poverty (pp. 21-58). ISEAS Publishing. doi.org/10.1355/9789812309600-008

Rozenberg, J. \& Fay, M. (2019). Overview. In J. Rozenberg \& M. Fay (Eds.), Beyond the gap: How countries can afford the infrastructure they need while protecting the planet (pp. 1-27). The World Bank. doi.org/10.1596/978-1-4648-1363-4_ov

Schmink, M., \& Wood, C. H. (1992). Contested frontiers in Amazonia. Columbia University Press.

Scoones, I. (1998). Sustainable rural livelihoods: A framework for analysis (IDS Working Paper 72). Institute of Development Studies. www.ids.ac.uk/publications/sustainablerural-livelihoods-a-framework-for-analysis/

Scoones, I. (2009). Livelihoods perspectives and rural development. The Journal of Peasant Studies, 36(1), 171-196. doi.org/10.1080/03066150902820503

Sloan, S., Campbell, M. J., Alamgir, M., Enger, J., Ishida, F. Y., Senn, N., Huther, J., \& Laurance, W. F. (2019). Hidden challenges for conservation and development along the Trans-Papuan economic corridor. Environmental Science and Policy, 92, 98-106. doi.org/ 10.1016/j.envsci.2018.11.011

UNESCO. (2004). State of conservation: Lorentz National Park (Indonesia). United Nations Educational, Scientific and Cultural Organization. whc.unesco.org/en/soc/1402 
UNESCO. (2017). State of conservation: Lorentz National Park (Indonesia). United Nations Educational, Scientific and Cultural Organization. whc.unesco.org/en/soc/2871

Wadley, R. L. (1998). The road to change in the Kapuas Hulu Borderlands: Jalan Lintas Utara. Borneo Research Bulletin, 29, 71-94.

Widjojo, M. S., Elisabeth, A., Al Rahab, A., Pamungkas, C., \& Dewi, R. (2010). Papua road map: Negotiating the past, improving the present and securing the future. Yayasan Pustaka Obor.

Wiegand, M., Koomen, E., Pradhan, M., \& Edmonds, C. (2017). The impact of road development on household welfare in rural Papua New Guinea (Tinbergen Institute Discussion Paper No. 17-076/V). Tinbergen Institute. doi.org/10.2139/ssrn.3021792 
This text is taken from Human Ecology Review, Volume 27, Number 1, 2021, published by ANU Press, The Australian National University, Canberra, Australia.

doi.org/10.22459/HER.27.01.2021.08 